\title{
Telling Big Little Lies: Writing the Female Gothic as extended metaphor in Complex television
}

Margaret McVeigh

Griffith Film School, Griffith University

Dr Margaret McVeigh, Ph.D., is Head of Screenwriting and Contextual Studies, Griffith Film School, Griffith University. She is a member of the SRN (Screenwriting Research Network International) Executive. Margaret holds a Master's of screenwriting by creative practice and a Ph.D. in film and new media narrative. She has extensive national and international industry experience in public relations and post-production and has worked as the commissioning editor for Wiley Publishers and as a writer for the Australian National Broadcaster's ABC Splash. Margaret is co-editor of Transcultural Screenwriting: Telling Stories for a Global World (2017). Her chapter, 'Work in progress: The writing of shortchanged' in The Palgrave Handbook of Film Production (2020) explores her creative process in writing a feature film, development-funded by Screen Queensland.

Gontact: Griffith Film School, Griffith University, Brisbane, Australia.

E-mail: m.mcveigh@griffith.edu.au

https://orcid.org/0000-0002-8307-3939

Abstract 
This article investigates the writing of the Female Gothic as extended metaphor in the Complex TV series Big Little Lies (2017). It builds on my earlier work, 'Theme and complex narrative structure in HBO's Big Little Lies 2017' (2019), wherein I applied Porter et al.'s (2002) Structuralist Narrative tool, the 'Scene Function Model', to investigate the way narrative and theme is progressed in complex interweaving stories via the writing of core or 'kernel' narrative scenes. Herein, I further investigate storytelling in series TV by proposing the 'satellite' narrative scene as a means by which the screenwriter may conceptualize and deploy metaphor to create viewer engagement. First, I consider David E. Kelley's series screenplay, Big Little Lies, as a blueprint for HBO's televised series. Specifically, I apply theories of Complex TV, Gothic Television and Domestic Noir to consider how Kelley deploys the Female Gothic as extended metaphor to inform formal narrative elements including the pre-titles sequences and flashbacks repeated across episodes.

Keywords

screenwriting

television

Big Little Lies

Complex TV

Female Gothic

screenwriting and metaphor

\section{Introduction}


Television narratives present a special case in writing and structuring stories for the screen. While there exist a number of highly regarded screenwriting manuals for the film (McKee 1999; Seger 2010; Aronson 2011), the literature around screenwriting for a contemporary television series like Big Little Lies is an emerging field. Australian screenwriting theorist, Linda Aronson's Television Writing: The Ground Rules of Series, Serials and Sitcom (2000) remains a classic 'how to' text for writing multiple storylines for series TV, even though the text is now dated with the emergence of 'Complex TV' (Mittell 2006, 2015) which has resulted in more creative structure, style and complex narrative scenarios in television series writing (Leverette et al. 2008). The establishment of the Journal of Screenwriting has seen an academic body of work specifically around TV screenwriting being established, including the Journal of Screenwriting special issue, 'Television Screenwriting: Continuity and Change' (Redvall and Cook 2015). However, only a handful of articles specifically focus on matters relating to writing for contemporary series TV. This includes Paolo Russo's article, 'Storylining engagement with repulsive antiheroes. Towards a cognitive poetics of TV serial drama narrative: The case of Gomorrah - The Series' (Russo 2017) in which he uses Smith (1995) and Blanchett and Bruun Vaage's (2012) viewer engagement theories to discuss how screenwriters' work enables engagement. It also includes Radha O'Meara's (2015) article, 'Changing the way we think about character change in episodic television series', which considers the transformation of characters in series TV via character action and plot structure, as opposed to the traditional view that characters in series TV are fixed. In addition, it includes Eva Novrup Redvall and Sabroe's (2016) article on 'Production design as a storytelling tool in the writing of the Danish TV drama series The Legacy', as well as Redvall's earlier and seminal book, Writing and Producing Television Drama in Denmark: From 'The Kingdom' to 'The Killing' (2013), where she considers key factors in the writing and development of Nordic Noir television series.

In this article, I align Screenwriting, Narrative and Critical Television studies to contribute to this emerging body of theory. It builds on my earlier work, 'Theme and complex narrative structure in HBO's Big Little Lies 2017' (2019), wherein I applied Porter et al.'s (2002) Structuralist Narrative tool, the 'Scene Function Model', to investigate the way narrative and theme is progressed in complex interweaving stories via the writing of core or 'kernel' narrative scenes. Herein, I further investigate storytelling in series TV by proposing the 'satellite' narrative scene as a means by which the screenwriter may conceptualize and deploy metaphor to create viewer engagement. Specifically, I consider David E. Kelley's series screenplay, Big Little Lies, as a 
blueprint for HBO's televised series. I apply theories of Complex TV, Gothic Television and Domestic Noir to consider how Kelley deploys the Female Gothic as an extended metaphor to inform formal narrative elements, including the pre-titles sequences and flashbacks repeated across episodes.

\section{Screenwriting theory and writing for series television}

HBO's Big Little Lies (2017) acclaimed limited television series won eight Emmy

Awards including Outstanding Limited Series. Writer Kelley was nominated for his work; director Jean-Marc Vallée and actors Nicole Kidman, Alexander Skasgard and Laura Dern won awards in their respective categories. The TV series is adapted from the Australian author, Liane Moriarty's book of the same name and is set in the tranquil seaside town of Monterey, California, where 'nothing is quite as it seems' (McVeigh 2019).

The telling of Big Little Lies uncovers the lies beneath the surface of the perfect world of immaculate mothers who "in the tradition of the Domestic Noir and the Female Gothic [...] are trapped in some way with troubled families in haunted mansions, and dark secrets wait to be revealed' (McVeigh 2019: n.pag). The series is centred around the investigation of a murder at the local school's annual Audrey Hepburn and Elvis themed Trivia night and unfolds from the multi-layered perspective of three mothers - Madeline (Reese Witherspoon), Celeste (Nicole Kidman) and Jane (Shailene Woodley).

In Big Little Lies 'the narrative world is the upmarket world of the mothers at the schoolyard gate and the community of Monterey' (McVeigh 2019: n.pag). Screenwriter, Kelley, notes, it is '[a] story about community. Love. Marriage. Relationships and how messy that equation can get' (Kelly 2017). As a limited series it is comprised of seven episodes:

1. 'Somebody's Dead'

2. 'Serious Mothering'

3. 'Living the Dream'

4. 'Push Comes to Shove'

5. 'Once Bitten'

6. 'Burning Love' 


\section{7. 'You Get What You Need'}

The narrative scenario of an enclosed world like Big Little Lies is central to theories of both Critical Television and Screenwriting for series TV. Critical Television theorist, Mittell, asserts that the aim of Complex TV is to create 'a sustained narrative world, populated by a consistent set of characters who experience a chain of events over time' (2015: 10). Similarly, Screenwriting theorist, Aronson, notes that the TV series presents the audience with:

A community with its own style and concerns [...] A group of compelling, clearly delineated characters $[\ldots]$ which functions like a family and demonstrates a range of ongoing problems, conflicts and ambivalences that are capable, if necessary, of being revisited every episode for three to five seasons. (2000:3)

Big Little Lies, evidences the traditional narrative structure of TV series storytelling with two to three key stories embroidered with those of lesser characters - the A story being the most important and the B story more important than the C story (Aronson 2000: 5). As is typical of screenwriting for a television series, the series arc, set up during the pilot, spans and builds during the series and is the main storyline across the series. It is a 'serial element $[\ldots]$ dealing with the private lives of the regular characters, particularly the emotional development and changes of each' which culminates in the final episode with 'the suspenseful climax' (Aronson 2000: 33).

In Big Little Lies, Story A is that of Madeline, the busy-body heart-of-gold mother who is the linking character across all stories. Story B is that of the ex-lawyer Celeste, the perfect wife and mother, and her controlling husband, Perry, and their seemingly innocent twin boys. Story $C$ is that of the outsider, Jane (Shailene Woodley), who moves from town to town. She is the 'down market' single mother with her son born of rape. The less important stories are Stories D and E. Story D is that of Renata Klein (Laura Dern), the high-powered IT CEO taking a day off work to take her child, Annabella, to school. Story E is that of laid-back earth mother, Bonnie (Zoe Kravitz), Madeline's ex-husband's second wife.

In Big Little Lies narrative complexity is also developed in the series arc by facets of the suburban noir and thriller/police procedural genres which are progressed in each episode. For example, in the suburban noir genre, dark secrets are hidden below the surface of suburbia. In Big Little Lies in each of the A, B, C, D and E stories, a secret or lie is revealed as outlined in Table 1. The tension and suspense elements of the thriller genre are developed in line with elements of the police procedural via the investigation of the murder at the climax of Episode 1. In 
Episode 7, the individual story arcs come to a resolution. As Aronson notes, '[t] needs to be considered in conjunction with the main story for each episode. Its progression needs to be planned with care. Suspense should be factored in' (2000: 33).

Kelley's storylining of Big Little Lies also demonstrates interweaving storylines, the hallmarks of 'Complex Television', which Mittell asserts in his groundbreaking article, 'Narrative complexity in contemporary American television' (2006), develops the simple storylines of earlier television series which may have offered 'thematic parallels or provide counterpoint to one another', but which rarely interacted. On the other hand, '[c]omplexity [...] [alters] the relationship between multiple plot lines, creating interweaving stories that often collide or coincide' (Mittell 2006: 34).

It is not within the scope of this article to provide a detailed analysis of the series arc and how the stories structurally interweave in each episode; however an overview of each storyline; its key characters; its narrative role in the complex narrative; and the elements of the Female Gothic metaphor set up in Episode 1, is tabled below.

\section{Table 1: Big Little Lies - Complex TV, Domestic Noir and Gothic Television.}

\begin{tabular}{|c|c|c|c|c|c|}
\hline Story & $\begin{array}{l}\text { Key } \\
\text { Characters }\end{array}$ & Complex Narrative & $\begin{array}{l}\text { Female Gothic } \\
\text { Storyline }\end{array}$ & $\begin{array}{l}\text { Female Gothic } \\
\text { Metaphors }\end{array}$ & Lie/Secret \\
\hline $\begin{array}{l}\text { Title } \\
\text { sequence }\end{array}$ & $\begin{array}{l}\text { Song lyrics: } \\
\text { Cold Little } \\
\text { Heart } \\
\text { (Kiwanuka, } \\
\text { 2016, 2017) }\end{array}$ & $\begin{array}{l}\text { Did you ever want } \\
\text { it? Did you want it } \\
\text { bad? Tears me } \\
\text { apart. We try to } \\
\text { hide it. It's all the } \\
\text { same [...] I know in } \\
\text { this world I can } \\
\text { leave or I can lie } \\
\text { [...] can you believe } \\
\text { in your lies? (From: } \\
\text { Cold Little Heart). }\end{array}$ & & $\begin{array}{l}\text { Sex scene hand } \\
\text { holding gun in } \\
\text { prologue. } \\
\text { Montage/Flashback } \\
\text { to footsteps in sand. } \\
\text { Barefoot girl running } \\
\text { on beach. } \\
\text { Barefoot girl in } \\
\text { evening dress } \\
\text { standing on beach. }\end{array}$ & \\
\hline Story A & $\begin{array}{l}\text { Madeline } \\
\text { Martha } \\
\text { McKenzie } \\
\text { (Reese } \\
\text { Witherspoon) }\end{array}$ & $\begin{array}{l}\text { Madeline is a busy } \\
\text { body with a heart of } \\
\text { gold. } \\
\text { She is married to } \\
\text { Ed and has a } \\
\text { daughter, Abigail, } \\
\text { with her ex- } \\
\text { husband, Nathan. } \\
\text { Hers is a portfolio } \\
\text { story connecting } \\
\text { Story B (Celeste) } \\
\text { and Story C (Jane). } \\
\text { Both Celeste and } \\
\text { Jane are the victims } \\
\text { of domestic } \\
\text { violence and rape. }\end{array}$ & $\begin{array}{l}\text { Sex scene and hand } \\
\text { holding gun in } \\
\text { prologue. } \\
\text { Montage/Flashback } \\
\text { to footsteps in } \\
\text { sand. } \\
\text { Barefoot girl } \\
\text { running on beach. } \\
\text { Barefoot girl in } \\
\text { evening dress } \\
\text { standing on beach. }\end{array}$ & $\begin{array}{l}\text { Madeline is trying to } \\
\text { hold her family } \\
\text { together in a } \\
\text { lacklustre marriage } \\
\text { and is challenged by } \\
\text { her teenage daughter. }\end{array}$ & $\begin{array}{l}\text { Madeline has } \\
\text { had an affair } \\
\text { she hides from } \\
\text { her husband. } \\
\text { Her marriage is } \\
\text { pedestrian. }\end{array}$ \\
\hline Story B & $\begin{array}{l}\text { Celeste } \\
\text { Wright } \\
\text { (Nicole } \\
\text { Kidman): }\end{array}$ & $\begin{array}{l}\text { Perfect and } \\
\text { beautiful Celeste } \\
\text { and her husband } \\
\text { Perry, seem too }\end{array}$ & $\begin{array}{l}\text { Celeste is the } \\
\text { victim of domestic } \\
\text { violence. }\end{array}$ & $\begin{array}{l}\text { Celeste is the victim } \\
\text { of domestic violence. }\end{array}$ & $\begin{array}{l}\text { Celeste Is the } \\
\text { victim of } \\
\text { domestic } \\
\text { violence. }\end{array}$ \\
\hline
\end{tabular}




\begin{tabular}{|c|c|c|c|c|c|}
\hline & $\begin{array}{l}\text { stay-at-home } \\
\text { mum, ex- } \\
\text { lawyer, } \\
\text { wealthy, } \\
\text { beautiful. }\end{array}$ & $\begin{array}{l}\text { "loved up". We see } \\
\text { Perry threaten } \\
\text { Celeste. } \\
\text { This story thread is } \\
\text { not resolved in this } \\
\text { episode. }\end{array}$ & & $\begin{array}{l}\text { Her twin boys are } \\
\text { playing with guns } \\
\text { and won't stop. } \\
\text { She is entrapped in } \\
\text { her mansion and also } \\
\text { in her role as the } \\
\text { perfect wife. }\end{array}$ & $\begin{array}{l}\text { Perry commits } \\
\text { domestic } \\
\text { violence and is } \\
\text { the person who } \\
\text { we later find } \\
\text { raped Jane. } \\
\text { Celeste's son, } \\
\text { Max is the } \\
\text { bully who } \\
\text { threatens } \\
\text { Renata's } \\
\text { daughter, } \\
\text { Annabella. }\end{array}$ \\
\hline Story $\mathrm{C}$ & $\begin{array}{l}\text { Jane } \\
\text { Chapman } \\
\text { (Shailene } \\
\text { Woodley) }\end{array}$ & $\begin{array}{l}\text { Jane is a single } \\
\text { mum and outsider. } \\
\text { Jane's son Ziggy is } \\
\text { accused of bullying } \\
\text { Renata's daughter, } \\
\text { Annabella. Jane } \\
\text { stands up for him. }\end{array}$ & $\begin{array}{l}\text { Jane has been } \\
\text { raped and Ziggy is } \\
\text { a child born of } \\
\text { rape. } \\
\text { Ziggy is accused of } \\
\text { bullying Renata's } \\
\text { daughter. }\end{array}$ & $\begin{array}{l}\text { Jane is the girl } \\
\text { running on beach. } \\
\text { She is also the girl in } \\
\text { evening dress } \\
\text { standing barefoot on } \\
\text { the beach. }\end{array}$ & $\begin{array}{l}\text { Jane has been } \\
\text { raped and her } \\
\text { son, Ziggy, is a } \\
\text { child born of } \\
\text { rape. } \\
\text { Ziggy is } \\
\text { accused of } \\
\text { bullying } \\
\text { Renata's } \\
\text { daughter. }\end{array}$ \\
\hline Story D & $\begin{array}{l}\text { Renata Klein } \\
\text { (Laura Dern) }\end{array}$ & $\begin{array}{l}\text { Renata is a high- } \\
\text { powered IT CEO } \\
\text { and working mum. } \\
\text { Her daughter, } \\
\text { Annabella, is } \\
\text { bullied at school. }\end{array}$ & $\begin{array}{l}\text { Renata's daughter } \\
\text { is bullied at school }\end{array}$ & $\begin{array}{l}\text { Renata is a working } \\
\text { mother, trapped in the } \\
\text { role of trying to "do it } \\
\text { all". }\end{array}$ & $\begin{array}{l}\text { Renata's } \\
\text { daughter, } \\
\text { Annabella, is } \\
\text { bullied at } \\
\text { school. }\end{array}$ \\
\hline Story E & $\begin{array}{l}\text { Bonnie } \\
\text { Carlson (Zoe } \\
\text { Kravitz) }\end{array}$ & $\begin{array}{l}\text { Bonnie is an earth } \\
\text { mother, yoga } \\
\text { teacher and stay-at- } \\
\text { home Mum. } \\
\text { Bonnie is married } \\
\text { to Madeline's ex- } \\
\text { husband, Nathan } \\
\text { with whom she has } \\
\text { a daughter, Skye. } \\
\text { Bonnie's sound } \\
\text { relationship with } \\
\text { her step-daughter, } \\
\text { Abigail, is a threat } \\
\text { to Madeline's } \\
\text { relationship with } \\
\text { Abigail. }\end{array}$ & $\begin{array}{l}\text { Bonnie is the } \\
\text { accidental } \\
\text { murderer. }\end{array}$ & $\begin{array}{l}\text { Bonnie commits a } \\
\text { crime. }\end{array}$ & $\begin{array}{l}\text { Bonnie is the } \\
\text { accidental } \\
\text { murderer. }\end{array}$ \\
\hline
\end{tabular}


Below, there follows in a more detailed discussion of Kelley's creation of the Female Gothic as metaphor in Episode 1 and across the episodes via Celeste's story, Story B, in terms of its 'narrative significance' but also its formal aesthetics for 'the visual pleasure' it provides, its 'texture, sensuality, and form', as part of the 'formal, sensory and "design" qualities of the artwork' (Cardwell cited in Richard 2018: 286). To this end, first I consider the role of metaphor in screenwriting, next I outline the key features of storytelling in the Female Gothic, and finally I trace how Kelley has used this metaphor to conjure the Female Gothic elements of unease, entrapment, violence, the violation of innocence and the hidden monstrous in Big Little Lies.

\section{Screenwriting and metaphor: The Female Gothic in Complex TV}

In screenwriting theory, the central precept of metaphor is a compelling tool used to create narrative, as well as the formal elements of form, style and visual sub-text. Screenwriter, Paul Schrader (Taxi Driver, Scorsese, 1976), underlines the power of metaphor in underscoring narrative, thematics and aesthetics in discussing the central metaphor of the acclaimed film, Taxi Driver:

To be a writer you should first examine and confront your own most pressing personal problems $[\ldots]$ When you find your problem, then come up with a metaphor for it. A metaphor is something that stands in place of the problem. It is not like the problem; it is another variation of the problem. Where this first came to me was with Taxi Driver; the problem was loneliness. The metaphor was the taxicab. The steel gaudy coffin floating through the sewers of New York, an iron box with a man inside who looked like he was in the middle of society, but in fact he was completely alone. The metaphor of the cab is so powerful that it can be treated as a metaphor for loneliness.

(Schrader cited in McGrath and MacDermott 2003: 14)

While there is little in print about Kelley's writing process for Big Little Lies, the publication, The Official Guide: Ally McBeal (1999), does provide a background to the way Kelley conceptualizes the central issues in a screenplay. Kelley's work includes procedural law series like LA Law (1986-94), The Practice (1997-2004) and Boston Legal (2004-08) and the female-driven series Ally McBeal (1997-2002). Elements of 
these series can be seen in the storylines driven by female issues and the police procedural aspects of Big Little Lies. When asked the following question about his writing, '[d]o you ever respond within the show to headlines about issues?' (1999: 10), Kelley replied:

If it's organic to the characters of our people, then I'm certainly willing to take on an issue and have fun with it, but I don't usually find an issue and then try to jury-rig it into the show. That's why most of our cases are a version of a man-woman issue or sexual harassment. It's really women and men struggling, striving to work together. (Appelo, 1999: 10)

At the heart of the Female Gothic metaphor is Kelley's 'version of a man-woman issue or sexual harassment' (2017a: 10) and in Big Little Lies, the reality of problems around domestic and sexual abuse: bullying, domestic violence and rape (McVeigh 2019). Big Little Lies draws on the genres of Gothic Television derived from Gothic Literature and Film and Domestic Noir, derived from Film Noir and the literary crime genre. Gothic theorist, Helen Wheatley defines Gothic Television 'as a domestic form of genre which is deeply concerned with the domestic, writing stories of unspeakable family secrets and homely trauma' where 'the female experience is the driving force of the [...] narrative' (2006: 1-2). Likewise, in the Domestic Noir literary genre, wherein the story revolves around a central crime, the female domestic experience is also at the centre of the narrative (Peters cited in Joyce and Sutton 2018: 12). In Domestic Noir, 'the main themes are family, motherhood, children, marriage, love, sex and betrayal [...] At the centre of these stories is a subversion of the idea of home as sanctuary' (Crouch cited in Joyce and Sutton 2018: v-vi). It is relevant to note that the home and the threat of the hidden monster and of domestic violence, are also key aspects of the Gothic. Gothic theorist, 
Mary Ann Doane's seminal work on the Female Gothic film, The Desire to Desire: The Woman's Film of the 1940's, notes the '[t]he paradigmatic woman's space - the home is yoked to dread, and to a crisis of vision. For violence is precisely what is hidden from sight' (Doane 1987: 134). Wheatley also notes '[t]he ultimate family secret present in the Female Gothic $[\ldots]$ is that of domestic violence. The discovery of child abuse and/or spousal brutality is the subtext' (Wheatley 2006: 109).

\title{
The Screenplay and Metaphor: Episode 1 Big Little Lies
}

\author{
Episode 1: Somebody's Dead
}

The opening sequence of Big Little Lies sets up the mood, tone and characters in the ensemble stories - all intercut in close-up and noir-style profile with vistas of the Monterey coast-line as they drive to school. There follows a montage of close-ups of crashing surf. The title song, Cold Little Heart plays under: 'Did you ever want it? Did you want it bad? Tears me apart. We try to hide it. It's all the same [...] I know in this world I can leave or I can lie [...] can you believe in your lies?'. (Kiwanuka [2016] 2017)

This song provides an inkling that there are lies beneath these parallel surfaces of conformity, a scenario pivotal to Domestic Noir and the Gothic. 
We see a close-up face to-camera parade of innocent kids at school - the children of the five key female characters - running towards camera. There follows a montage of close-ups of crashing surf intercut with images under - suggestive of a couple having sex on the beach - again a visual portent of unease - then again under - a hand cocking a gun - the next inkling of domestic noir and hidden violence. Then follows an out-ofcontext parade of mothers in Audrey Hepburn costume.

Fade to and up from black to flashing police lights, heavy breathing, evidence of a crime - the next element of Domestic Noir - whip pans, glimpses of the still of a crudely drawn Elvis, people standing as if in shock looking on, snippets of voice over, flashes of images and flash pans. A man and a woman are walking. Police. The man is the first character to speak. 'Is this a costume night or somethin'?' We learn that a murder has occurred at the trivia night of a Monterey public school but the victim or murderer are not revealed. The cop says that there is 'Not a lot of clarity'. This is a sequence that will be similarly repeated at the conclusion to Episode Seven.

We cut to close-ups of police interviews of unknown characters - like a Greek Chorus - revealing their interpretation of the event, but really revealing the festering atmosphere of competition and show that drives the women who impel this story. Lead into the last interviewee's comment, 'now the root of it was Madeline Mackenzie'. Of this episode, wherein the foundations of the intrigue and secrecy of the Female Gothic are seeded, 
screenwriter David E. Kelley notes, 'The goal is to build the intrigue but also to occasion the audience that something else is going on here behind these outward appearances' (2017).

In Big Little Lies the majority of scenes unfold in the home where we see the key female characters with their families. It is here we learn the secrets they are hiding. In literary theory the Female Gothic has been identified as a reflection of perceived position of powerlessness of women in a patriarchal society and has led to the development of a 'familiar set of narratives that revolve around an innocent and blameless heroine threatened by a powerful male figure and confined to a labyrinthine interior space'.

(Brabon and Genz 2007: 5)

In each of the Stories A, B and D, the female protagonists, Madeline, Celeste and Renata, are trapped in roles they do not wish to play. Madeline is trapped in a pedestrian marriage and has an affair to break out. Celeste is trapped both as a stay-at-home mother who wishes to use her skills as a lawyer and as a victim of domestic violence at the hand of her husband, Perry. In Story D, Renata wants to live a different life even though she appears to have it all. She makes the community upset by accusing Jane's son, Ziggy, of bullying her daughter. However, it is in Stories B and C that we find the stark storyline of the Female Gothic, the 'innocent and blameless heroine' who hides 'secrets from the past' and lives in 'homes and families which are haunted, tortured or troubled in some way' (Wheatley 2006: 3). Celeste is trapped 
in a violent marriage. Jane's innocence has been destroyed by rape. Their stories will connect via Perry, Celeste's husband, when in the final episode at the Trivia night, Jane first meets Perry in the series and recognizes him as the man who raped her.

In further discussing David E. Kelley's deployment of Gothic Narrative in Big Little Lies, at the narrative and formal level, below, I consider Story B, Celeste's story across the episodes of the series and where relevant, comment on other stories as they interweave and inflect the Female Gothic.

In Episode One, we meet Celeste at home in her immaculate mansion with her husband Perry. Their kids are playing with toy guns, a symbol which we will later see becomes a pivotal narrative element in Jane's story. Later Celeste is arranging happy family shots on a computer in a darkened room when Perry challenges and threatens her to make sure that their boys stay away from the accused bully, Ziggy. Actor, Alexander Skasgard, who plays Perry, notes:

Perry and Celeste have a passionate love life. He lives in this incredible house up in Monterey. It's the perfect life. Then towards the end of the first episode, there's a moment where it gets a little darker you realize that there's another side to Perry (Skasgard, 2017).

The 'big print' for this scene as written by Kelley in Episode One reads:

This is scary now. Could it actually get violent? Finally, he releases. She holds a dagger-glare, then exits the room. 
In Episode 2: Serious Mothering, Perry lashes out at Celeste when he discovers she has missed school orientation. This is the second time we get a sense that their 'loved up' life may not be all it seems. Madeline goes on the warpath with Renata when she discovers she didn't invite Ziggy to Annabella's birthday party. Madeline's younger daughter, Chloe, and Bonnie's daughter, Skye, try to smooth things over between Ziggy and Annabella but it leads to incident of unwanted touching. For Jane, this sparks a flashback to the rape which resulted in Ziggy's conception. In Episode 3: Living the Dream, in the B Story, Perry chokes Celeste when he thinks he has been left out of their sons' birthday party. She threatens to leave him. In the C Story, Jane confides to Madeline that Ziggy is born of rape. In Episode 4: Push Comes to Shove, in Story B, Celeste reflects on her entrapment in the role she plays as the stay-at-home Mum after she represents Ziggy bona fide in defense of his purported bullying. She says, 'Today I felt alive. I felt good. Is that crazy? I so ashamed for saying this but being a mother is not enough for me'. She asks her therapist how to raise this idea with Perry. The therapist is concerned why she cannot. Celeste tells Perry and he grabs her by the throat.

In Episode 5: Once Bitten, in Story D, Renata discovers a bite mark on Annabella's arm. She assumes it is Ziggy and demands a meeting with the Principal and Jane and Ziggy. This is story D meeting story C, and it embroiders the bullying thematic of domestic violence and the Female 
Gothic. Jane is concerned people will find that Ziggy is born of rape. In this episode Jean Marc Vallee notes, 'We were suggesting danger that Jane had secrets and they may be dark $[\ldots]$ the way we see life through Jane's prism may not be completely accurate, so we were inviting the audience to ask, "is this real or is this Jane's perception?"'. ('Once Bitten: Big Little Lies Inside the Episode' 2017)

In Episode 6: Burning Love, the violence escalates across all the stories. Story C meets Story A when Jane tells Madeline she went to confront and shoot Saxon Baker, the man whom Madeline thinks may have raped Jane and whom we learn was not the rapist. The teacher tells Jane a petition has been started to have Ziggy suspended for bullying. In story C meets Story D, Jane confronts Renata assuming she is the instigator of the petition and in the heat-of-the-moment, gouges her eye. In Story B, Celeste's therapist advises her to leave Perry and rent an apartment and disclose the abuse to her friends. Perry tries to have sex with Celeste who refuses. She hits him in the groin with a tennis racket, fracturing his penis. Perry gets out of hospital and when he comes home, tells Celeste she is lucky he did not kill her. The next day Celeste begins looking for an apartment. In the final episode, Episode 7: You Get What You Need, the day of the Trivia night extends for most of the episode. In Story B, Celeste is beaten again and finally decides to leave Perry that day. This action on Celeste's part to escape the threatening domestic space, illustrates a significant feature of the Female Gothic where 'More often than not, these narratives also centre around the heroine's departure from $[\ldots]$ a threatening marital 
home, and her eventual escape to the independence of a home of her own' (Wheatley 2006: 92). In Story C, Ziggy confesses to Jane that it was Max, Celeste's son, who choked Annabella and that he has also been violent towards Skye, Bonnie's daughter. In Story C meets Story B, Jane tells Celeste her son Max is a bully and Celeste goes home to ask Max to be truthful to her. In Story B, Perry sees a text on Celeste's phone from her new landlady and he confronts her on the way to the party. Perry tries to stop Celeste leaving the car when they get to the party but she escapes. At the party, in Story B meets story D, Celeste avoids Perry and tells Renata that Max is the bully.

It is here that all the stories interweave for the climax. In Story A, Madeline is drunk and runs away from her husband, Ed. In Story C, Jane goes after her and finds her at the top of a set of concrete stairs crying. In Story D, Renata also goes after them and apologizes to Jane for blaming Ziggy. In Story B, Celeste joins them but she is followed by Perry. In Story E, Bonnie has been following Celeste and Perry from a distance as she noticed them arguing. It is then that Jane realizes that Perry is the man who raped her. All the women converge on him. Perry pleads to Celeste to come back to him and when she says 'no' he attacks Madeline. Jane and Renata try to hold Perry back. The unlikely Bonnie rushes in and pushes Perry down the stairs. He is killed.

In the resolution we see the bookend to the opening. The police interviews continue. The women all confirm there was a fight with Perry but that he fell accidentally. Nothing can 
be proved as their stories match. In an echo of the voyeur policeman in the first scene of Episode 1, we close in on the women together on the beach with the policeman watching them through binoculars. As an actor and an executive producer, Nicole Kidman notes: '[y]ou can laugh with them and play with them. All of the violence and complications intertwine into their relationship' (2017: n.pag). Ultimately in this series, it would seem the women have escaped the confines of the Female Gothic by reaffirming the sisterhood and ironically, sharing the ongoing secret of who Perry's murderer really is.

\section{Complex TV - A storytelling mode}

In the section above I have outlined the narrative and formal elements of the Female Gothic that Kelley has included in the script, but from the perspective of screenwriting theory, how may we conceptualize patterns for writing metaphor across a television series?

For Mittell the complex and elliptical narrative of contemporary TV series requires a 'poetic approach' to untangle its narrative threads and evaluate 'how serial television can reach aesthetic achievements' (2015: 216). Of significance to this article, is Mittell's contention that the basic precept of the poetic approach is one that focuses on 'the specific ways that texts make meaning, concerned with the formal aspects of media more than issues of content and broader cultural forces', the guiding question being, 'how does this text work?' (Mittell 2015: 5).

To this end, in my earlier article on Big Little Lies, 'Theme and complex narrative structure in HBO's Big Little Lies (2017)', I deployed Porter et al.'s (2002) Scene Function Model, based on Narratologist, Seymour Chatman's work, to 'examine the narrative structure of Big Little Lies to consider the rules and patterns of television narrative that are used to create meaning' (McVeigh 2019: n.pag). As a tool for the analysis of a television series story the Scene Function Model 'identifies specific, discrete narrative functions within a scene that show how (sic) those scenes advance or enhance the narrative. The instrument requires the user to ask the basic question: What is the function/purpose of this scene for the telling of the story?' (Porter et al. 2002: 25). In the aforementioned article, I applied the notion of Porter et al.'s six core narrative or 'kernel' scene functions - disturbance, obstacle, complication, confrontation, crisis and resolution (2002: 26) to the A, B, C, D and E stories in Episode 1. I found that the kernel scenes of Story A, B and C had primacy, with a relationship in each of these stories being the focus of the episode. On the other hand, I found that the $D$ and $E$ stories were more open-ended with sequences playing out to underline the thematics of the $A, B$ and $C$ stories, rather than as a 
discrete story within themselves (McVeigh 2019). Overall I found, as outlined in Table 2, that the Scene Function Model provided an able structural tool to analyse the key narrative events, the kernel scenes, at the behest of developing the themes of Big Little Lies.

Table 2: $\quad$ Big Little Lies - Episode 1: 'Somebody's Dead' storylines, Kernel scenes

\begin{tabular}{|c|c|c|c|c|c|}
\hline Scene Functions & $\begin{array}{l}\text { Story A } \\
\text { Madeline }\end{array}$ & $\begin{array}{c}\text { Story B } \\
\text { Celeste }\end{array}$ & Jane ${ }^{\text {Story } \mathbf{C}}$ & $\begin{array}{l}\text { Story D } \\
\text { Renata }\end{array}$ & $\begin{array}{c}\text { Story E } \\
\text { Bonnie }\end{array}$ \\
\hline $\begin{array}{l}\text { KERNEL } \\
\text { SCENES } \\
\text { Disturbance } \\
\text { Obstacle } \\
\text { Complications } \\
\text { Crisis } \\
\text { Resolution }\end{array}$ & $\begin{array}{l}\text { Portfolio story } \\
\text { connecting } \\
\text { Celeste and Jane } \\
\text { who are the } \\
\text { victims of } \\
\text { domestic } \\
\text { violence and } \\
\text { rape. Madeline } \\
\text { is trying to hold } \\
\text { her family } \\
\text { together when } \\
\text { challenged by } \\
\text { her teenage } \\
\text { daughter. This } \\
\text { story thread is } \\
\text { resolved in this } \\
\text { episode. }\end{array}$ & $\begin{array}{l}\text { Perfect and } \\
\text { beautiful } \\
\text { Celeste \& her } \\
\text { husband Perry } \\
\text { seem too loved } \\
\text { up. Kids are } \\
\text { playing with } \\
\text { guns and won't } \\
\text { stop. We see } \\
\text { Perry threaten } \\
\text { Celeste. This } \\
\text { story thread is } \\
\text { not resolved in } \\
\text { this episode. }\end{array}$ & $\begin{array}{l}\text { Single Mum \& } \\
\text { outsider Jane's } \\
\text { son Ziggy is } \\
\text { accused of } \\
\text { bullying } \\
\text { Annabella. Jane } \\
\text { stands up for } \\
\text { him. This story } \\
\text { thread is not } \\
\text { resolved in this } \\
\text { episode. }\end{array}$ & $\begin{array}{l}\text { Perfect working } \\
\text { mum and CEO } \\
\text { Renata's } \\
\text { daughter } \\
\text { Annabella is } \\
\text { bullied. This } \\
\text { story thread is } \\
\text { not resolved in } \\
\text { this episode. }\end{array}$ & $\begin{array}{l}\text { Zen stay at } \\
\text { home Mum Zoe } \\
\text { is a threat to } \\
\text { Madeline whose } \\
\text { daughter is her } \\
\text { step-daughter. } \\
\text { This story } \\
\text { thread is not } \\
\text { resolved in this } \\
\text { episode. }\end{array}$ \\
\hline
\end{tabular}

From: (McVeigh, 2019: n.pag)

However, I also found, as outlined in Table 3, that there were also sequences and important elements including music and lyrics, elliptical montages and re-occurring images in flashbacks which did not overtly serve to develop the narrative. They evidenced the Complex TV features of the reordering of events 'through flashbacks, retelling past events, repeating story events from multiple perspectives, and jumbling chronologies' (Mittell 2015: 26).

Table 3: Big Little Lies - Satellite scenes and Female Gothic thematic, Episode 1:

'Somebody's Dead'. 
Title Song: Cold Little Heart lyrics: Did you ever want it? Did you want it bad? Tears me apart. We try to hide it. It's all the same... I know in this world I can leave or I can lie ... can you believe in your lies?

\begin{tabular}{|c|c|c|c|c|c|}
\hline Scene Functions & $\begin{array}{c}\text { Story A } \\
\text { Madeline }\end{array}$ & $\begin{array}{l}\text { Story B } \\
\text { Celeste }\end{array}$ & $\begin{array}{l}\text { Story C } \\
\text { Jane }\end{array}$ & $\begin{array}{c}\text { Story D } \\
\text { Renata }\end{array}$ & $\begin{array}{l}\text { Story E } \\
\text { Bonnie }\end{array}$ \\
\hline \multicolumn{6}{|l|}{$\begin{array}{l}\text { SATELLITE } \\
\text { SCENES }\end{array}$} \\
\hline $\begin{array}{l}\text { PROLOGUE \& } \\
\text { TITLES }\end{array}$ & $\begin{array}{l}\text { Stay at home } \\
\text { Mum driving } \\
\text { daughter to } \\
\text { school }\end{array}$ & $\begin{array}{l}\text { Stay at home } \\
\text { Mum driving } \\
\text { twin boys to } \\
\text { school }\end{array}$ & $\begin{array}{l}\text { Stay at home } \\
\text { Mum driving } \\
\text { son to school }\end{array}$ & $\begin{array}{l}\text { Stay at home } \\
\text { Mum driving } \\
\text { daughter to } \\
\text { school }\end{array}$ & $\begin{array}{l}\text { Stay at home } \\
\text { Mum driving } \\
\text { daughter to } \\
\text { school }\end{array}$ \\
\hline Exposition & $\begin{array}{l}\text { Flashing police } \\
\text { lights at school } \\
\text { trivia night. } \\
\text { Whip pans. } \\
\text { Heavy breathing }\end{array}$ & $\begin{array}{l}\text { Flashing police } \\
\text { lights at school } \\
\text { trivia night }\end{array}$ & $\begin{array}{l}\text { Flashing police } \\
\text { lights at school } \\
\text { trivia night }\end{array}$ & $\begin{array}{l}\text { Flashing police } \\
\text { lights at school } \\
\text { trivia night }\end{array}$ & $\begin{array}{l}\text { Flashing police } \\
\text { lights at school } \\
\text { trivia night }\end{array}$ \\
\hline $\begin{array}{l}\text { Dramatic } \\
\text { question }\end{array}$ & $\begin{array}{l}\text { Who has been } \\
\text { murdered? } \\
\text { Who is the } \\
\text { murderer? }\end{array}$ & $\begin{array}{l}\text { Who has been } \\
\text { murdered? } \\
\text { Who is the } \\
\text { murderer? }\end{array}$ & $\begin{array}{l}\text { Who has been } \\
\text { murdered? } \\
\text { Who is the } \\
\text { murderer? }\end{array}$ & $\begin{array}{l}\text { Who has been } \\
\text { murdered? } \\
\text { Who is the } \\
\text { murderer? }\end{array}$ & $\begin{array}{l}\text { Who has been } \\
\text { murdered? } \\
\text { Who is the } \\
\text { murderer? }\end{array}$ \\
\hline Theme & $\begin{array}{l}\text { Song: "Victim } \\
\text { of Love". }\end{array}$ & $\begin{array}{l}\text { Song: "Victim } \\
\text { of Love". }\end{array}$ & & $\begin{array}{l}\text { Renata says, } \\
\text { "Little boys } \\
\text { don't go around } \\
\text { anymore hurting } \\
\text { any girls." }\end{array}$ & $\begin{array}{l}\text { Bonnie tells } \\
\text { Nathan, "None } \\
\text { of us see things } \\
\text { as they really } \\
\text { are." }\end{array}$ \\
\hline Foreshadowing & $\begin{array}{l}\text { Pre-titles } \\
\text { sequence and } \\
\text { montage } \\
\text { includes a sex } \\
\text { scene and a } \\
\text { hand holding a } \\
\text { gun. }\end{array}$ & $\begin{array}{l}\text { Pre-titles } \\
\text { sequence and } \\
\text { montage } \\
\text { includes a sex } \\
\text { scene and a } \\
\text { hand holding a } \\
\text { gun. }\end{array}$ & $\begin{array}{l}\text { Pre-titles } \\
\text { sequence and } \\
\text { montage } \\
\text { includes a sex } \\
\text { scene and a } \\
\text { hand holding a } \\
\text { gun. } \\
\text { Flashback to } \\
\text { footsteps in the } \\
\text { sand a girl } \\
\text { whom we learn } \\
\text { is Jane, running } \\
\text { barefoot on the } \\
\text { beach in an } \\
\text { evening dress. }\end{array}$ & $\begin{array}{l}\text { Pre-titles } \\
\text { sequence and } \\
\text { montage } \\
\text { includes a sex } \\
\text { scene and a } \\
\text { hand holding a } \\
\text { gun. }\end{array}$ & $\begin{array}{l}\text { Pre-titles } \\
\text { sequence and } \\
\text { montage } \\
\text { includes a sex } \\
\text { scene and a } \\
\text { hand holding a } \\
\text { gun. }\end{array}$ \\
\hline
\end{tabular}

Herein, I propose that a screenwriter may conceive of these as 'satellite scenes' for, even though they do not move the story along, they are not superfluous for they make the story 'richer and fuller' (Porter et al. 2002: 26). Satellite scenes may serve any of twelve functions: exposition, dramatic question, introduction of new character, action, plan revealed, relationship affirmation, clarification, conflict continues, relief, theme, foreshadowing and ambiance (Porter et al. 2002). Mittell also notes the distinction between and 'satellite' scenes which he terms the narrative enigma and 'kernel' scenes which he terms the narrative statement (2015: 18-19). For Mittell the narrative statement moves the narrative forward and is essential to the comprehension of the narrative, while the narrative enigma provides 'texture, tone and character richness' which raises 'uncertainty about what actually happened, who was involved, why they did what they did, how this came to be, or even whether it actually happened at all' (Mittell 2015: 24-25). It is these scenes that I contend that may be conceptualized by the writer 
in terms of the Female Gothic - the non-narrative and formal elements of a screenplay including - the elliptical, metaphorical, out-of-context visual elements and contextual song lyrics. To this end, in the next sections I consider elements of Kelley's screenplay for Big Little Lies as a blueprint for what could be considered the 'satellite scenes' or narrative enigma, the scenes and sequences that create 'potential pleasures, interpretations, and modes of engagement for its viewers' (Mittell 2015: 6).

\section{Storylining for engagement: Televisuality and the Female Gothic}

\section{in Complex TV}

For Mittell, narrative complexity attests a formal innovation in series TV storytelling which incorporates modes of art cinema narration including the use of flashbacks, dream sequences, narrative twists and increased demands on viewer engagement including disorientation and confusion (Mittell 2006: 36-38). Similarly, Gothic narrative can unfold via 'repetitions, returns, deja-vu, premonitions' (Wheatley 2006: 3).

In Episode 1 of both the script and the series, we find the following scene which details Jane's continuing flashbacks. The screenplay for these intermittent flashbacks, repeated at intervals across the series, as it incrementally provides more narrative detail of the rape, is a case-in-point example of the use of flashback, dream sequences and the demand on viewer engagement central to the storytelling mode of Complex TV.

From Big Little Lies Script: Episode 1: 'Somebody's Dead'.

A WALKING POINT OF VIEW, at dawn, as we follow footsteps on the beach from a single person, apparently a man, since the imprints on the sand are from male shoes. They haven't been washed away yet by the waves that are coming in and out of frame, almost touching the footsteps. The person was walking close to the water. Not too long ago. We stop when suddenly we notice that there are no more footsteps ahead, nor to the right towards the ocean; nor to the left, as if the person had vanished.

(Big Little Lies Script 2017a, 1: 127)

This scene, as written, translates directly from page to the screen. It is impressionistic, apparently devoid of narrative causality, a dreamlike montage of random images which, in the soft-focus blue-toned filmic rendition, suggests that this is a flashback. But as we 
will learn later, it is a vital element of Jane's story and is repeated at other times across the episodes when Jane finds herself challenged by what is happening in her life. These narrative and metaphorical elements are also key genre elements of the Female Gothic. As Wheatley notes:

The Female Gothic television drama centres on the point of view of the central female protagonist $[\ldots]$ moments of marked subjectivity frequently evoked $[\ldots]$ are fantasy or dream flashbacks, often shown as an impressionistic montage of images from the past, present and the future of the drama. These psychical point-of-view sequences, often occurring at moments of crisis for the heroine, build up an impression of the narrative in non-linear or non-chronological order, suggesting the significance of certain images, sounds and events without fully elucidating the drama's central enigma $[\ldots]$ which must be uncovered in order to resolve the narrative. (2006: 111-13)

For the screenwriter, if we conceptualize Jane's flashback scene via its aesthetic function, as a satellite scene, we can consider its narrative and metaphorical purpose. For example, as a satellite scene of 'exposition', we find out more and more about the rape. As a satellite scene of 'dramatic question', we ask, '[w]hat is happening?' and then as we find out more, '[w] hat is happening to Jane?'. As a satellite scene of 'theme', this scene underlies the metaphor of the Female Gothic in the violence of the rape. As a satellite scene of 'foreshadowing', Jane's last flashback merges into a flash forward of the women attacking Perry at the climax. Director, Jean Marc Vallee observes of this scene, that for the character of Jane:

She's gonna talk about it and then we see it. She's gonna have an out of body experience and this is how we are going to show the rape. The shoes. The specific heel will allow us to have the footsteps in the sand and the specific footsteps. It was so heartbreaking and then she goes on the beach and she goes into the ocean naked to cleanse herself. This 
explains the recurring flashback of a woman in her evening gown running on the beach.

('Living the Dream: Big Little Lies Inside the Episode' 2017)

The repeated titles sequence also provides another example of the potential for a screenwriter to create narrative enigma via the techniques of art-house cinema and televisuality, as does Kelley. As noted above, the title sequence commences with the women intercut with the crashing surf of Monterey as they drive their children to school. It is immediately followed by a montage of images which bleed into the sequence that situates the series in a crime central to Domestic Noir. While the scenes below do not translate directly from script to screen in terms of chronological screen time (the first extract at scene 300 is the introduction to Episode 3, and the second extract at scene 127, is the conclusion to Episode 1), they are an exact rendition of the script and have been combined in the series to create the repeated opening title sequence across all episodes.

From Big Little Lies Script: Episode 3: 'Living the Dream'

A BIG SURF, WAVES CRASHING, EXPLODING AGAINST THE ROCKY

SHORELINE. THE OCEAN ROARS. A BIT LIKE A DEATH ROAR.

ANGLE JANE. (2017: 300)

From Big Little Lies Script: Episode 1: 'Somebody's Dead'

BLURRY FLURRIES OF LIGHTS, CAMERA FLASHES AND GLIMPSES OF

different Elvis Presleys and Audrey Hepburns. A LOUD, CRYING HARMONICA

STARTLES US WHEN WE SEE FLASHES OF NAKED FLESH: BODY PARTS OF A

MAN AND A WOMAN, HARD TO TELL IF THEY ARE HAVING SEX, OR

TRYING TO KILL EACH OTHER.

END CREDITS over the mystery and sexy vibe of 'THE RAINBOW' from Talk Talk

that sets the tone for what's coming and [...]. (2017: 127)

The significance of Kelley's elliptical, impressionistic and metaphorical screenwriting in Big Little Lies is evidence of a key storytelling tool in the Complex TV storytelling mode 
where apparently unrelated elements are juxtaposed to contribute to the narrative on a number of levels. Kelley's screenwriting is an exemplar of the script as a blueprint for Caldwell's notion of the aesthetic and sensory function of the televisual where the viewer is engaged by ascribing 'to the fragmented flow a sense of intelligibility and logic' (1995: 179) because:

On one level the title sequences flaunt authorial power by orchestrating a multitude of images within a single frame $[\ldots]$ these decorative elements also provide extensive narrative detail $[\ldots]$ The fact that this loaded visual world is spinning and flying past the [...] Formal ruptures [...] are used to pace the manic narrative, to anchor the characters, and to give retroactive causality to the narrative actions. (Caldwell 1995: 179)

Satellite scene functions may be analysed in terms of how they contribute to the formal elements of the story via techniques such as flashback and foreshadowing - Mittell's narrative enigma and Caldwell's televisuality. I therefore argue that these 'satellite scenes' or narrative enigmas are actually key aesthetic storytelling tools that may be used by the screenwriter to develop narrative and formal complexity in Complex TV. Moreover, while satellite scenes may serve to underline the thematic, in the case of Big Little Lies, domestic violence, bullying and rape, they can also serve to create suspense and build 'intrigue but also to occasion the audience that something else is going on here behind these outward appearances' (Kelley 2017b: n.pag).

Therefore, in this article, I suggest that if we are to conceptualize Kelley's writing of the satellite elements of 'exposition, theme, foreshadowing, and ambiance' in terms of their narrative and aesthetic significance, they may be understood as vital elements in the creation of sustained metaphor across a Complex TV series. Mittell suggests, '[o]ne of the pleasures of consuming a serialized narrative is trying to figure out whether a given event might be a kernel or a satellite in the larger arc of plot-line or series as a whole' (Mittell 2015: 24). 
It is how to engage and audience by writing this 'pleasure' in a screenplay that this article has investigated.

\section{Conclusion}

The aim of this article was to consider how the screenwriter may use a metaphor, and in the case of Big Little Lies, the metaphor of the Female Gothic, to drive both the narrative and aesthetics of a Complex TV series. The discussion has been guided by Mittell's assertion that the complex and elliptical narrative of contemporary TV series requires a 'poetic approach' to untangle and evaluate its narrative and aesthetics (2015: 216). In this article, the untangling of the narrative threads and the exploration of the metaphor of the Female Gothic in Big Little Lies, was investigated by applying the Scene Function Model and its notion of the 'satellite scene' - Mittell's narrative enigma - as a means of reflecting 'on the meaning of the form even as one feels drawn into the pleasure of the gradually unfolding narrative' (Anderson cited in Edgerton and Jones 2009: 25). I have considered how the complex and elliptical nature of a Complex TV series, with its use of flashback, flash-forward, montage, song lyrics and metaphorical associations, may be envisaged by the screenwriter at script level in terms of its narrative, televisual and aesthetic import by the deployment of an overarching metaphor like the Female Gothic.

\section{References}

Anderson, Christopher (2009), 'Drama overview', in G. R. Edgerton and J. P. Jones (eds), The Essential HBO Reader, Lexington : University Press of Kentucky, pp. 23-41.

Appelo, Tim (1999), The Official Guide: Ally McBeal, New York: Twentieth Century Fox Corporation and Harper Perennial.

Aronson, Linda (2000), Television Writing: The Ground Rules of Series, Serials and Sitcom, Sydney: AFTRS. 
(2011), The 21st Century Screenplay: A Comprehensive Guide to Writing

Tomorrow's Films, Crows Nest, N.S.W.: Allen and Unwin.

Brabon, Benjamin A. and Genz, Stéphanie (eds) (2007), Postfeminist Gothic Critical Interventions in Contemporary Culture, Basingstoke and Hampshire: Pan Macmillan.

Caldwell, John Thornton (1995), Televisuality: Style, Crisis and Authority in American Television, New Brunswick, NJ: Rutgers University Press.

Cardwell, Sarah (2013), 'Television aesthetics: Stylistic analysis and beyond', in J. Jacobs and S. Peacock (eds), Television Aesthetics and Style, London: Bloomsbury, pp. 23-44.

Chatman, Seymour (1994), Story and Discourse: Narrative Strategies in Fiction and Film, Ithaca, N.Y.: Cornell University Press.

Crouch, Julia (2018), 'Foreward: Notes from a genre bender', in L. Joyce and H. Sutton (eds), Domestic Noir: The New Face of 21st Century Crime Fiction, London, UK: Palgrave Macmillan, pp. v-viii.

Doane, Mary Ann (1987), The Desire to Desire: The Woman's Film of the 1940's, Bloomington, IN: Indiana University Press.

Edgerton, Gary R. and Jones, Jeffrey P. (eds) (2009), The Essential HBO Reader, Lexington: University Press of Kentucky.

Joyce, Laura and Sutton, Henry (eds) (2018) Domestic Noir The New Face of 21st Century Crime Fiction, London, UK: Palgrave Macmillan. 
Kelley, David E. (2017a), Big Little Lies, Scripts for Episodes 1-7,

@ https://www.emmys.com/awards/2017/limited-series-or-movie-scripts. Accessed 10 April 2018.

(2017b), interview with writer, About Big Little Lies, DVD extras, New York, USA: HBO (Home Box Office).

Kidman, Nicole (2017), 'Executive producer and lead actor', About Big Little Lies, DVD extras, New York, USA: HBO (Home Box Office).

Kiwanuka, Michael ([2016] 2017), ““Cold Little Heart” from Love \& Hate’, Big Little Lies, extras, New York, USA: HBO (Home Box Office).

Leverette, Marc, Ott, Brian L. and Buckley, Cara Louise (eds) (2008), It's Not TV Watching $H B O$ in the Post-Television Era, New York: Routledge.

'Living the Dream: Big Little Lies Inside the Episode: Episode 3' (2017), Jean-Marc Vallee (dir.), Big Little Lies, Season 1, Episode 3, New York, USA: (HBO [Home Box Office]).

McGrath, Declan, and MacDermott, Felim (2002), Screenwriting. Mies: RotoVision.

McKee, Robert (1999), Story: Substance, Structure, Style and the Principles of Screenwriting, London: Methuen.

McVeigh, Margaret (2019), 'Confronting reality: Theme \& complex narrative structure in HBO's Big Little Lies', Refractory: A Journal of Entertainment Media, Special Issue: 'ASPERA', 33, 6 October. n.pag.

Mittell, Jason (2006), 'Narrative complexity in contemporary American television', The Velvet Light Trap, 58: Fall, pp. 29-40. 
(2015), Complex TV: The Poetics of Contemporary Television Storytelling, New York: New York University Press.

Moriarty, Liane (2014), Big Little Lies, Sydney: Pan Macmillan.

O’Meara, Radha (2015), 'Changing the way we think about character change in episodic television series', Journal of Screenwriting, 6:2, June, pp. 189-201.

'Once Bitten: Big Little Lies Inside the Episode: Episode 5'’ (2017), Jean-Marc Vallee (dir.), Big Little Lies, Season 1, Episode 5, New York, USA: (HBO [Home Box Office]).

Peters, Fiona (2018), 'The literary antecedents of domestic noir', in L. Joyce and H. Sutton (eds), Domestic Noir: The New Face of 21st Century Crime Fiction, London, UK: Palgrave Macmillan, pp. 11-25.

Porter, Michael J., Larson, Deborah L., Harthcock, Alison and Nellis, Kelley Berg (2002), 'Re-defining narrative events: Examining television narrative structure', Journal of Popular Film and Television, 30:1 (Spring), pp. 23-30.

Redvall, Eva Novrup (2013), Writing and Producing Television Drama in Denmark:

From the Kingdom to the Killing, London, UK: Palgrave Macmillan.

Redvall, Eva N. and Cook, John R. (eds) (2015), Journal of Screenwriting, Special Issue:

'Television Screenwriting: Continuity and Change', 6:2, Bristol: Intellect.

Redvall, Eva Novrup and Sabroe, Iben Albinus (2016), 'Production design as a storytelling tool in the writing of the Danish TV drama series The Legacy', Journal of Screenwriting, 7:3, 1 September, pp. 299-317.

Richard, David Evan (2018), 'People in glass houses: Big Little Lies on the small screen', Adaptation: The Journal of Literature on Screen Studies, .Volume 11, Issue 3, December 
Russo, Paolo (2017), 'Storylining engagement with repulsive antiheroes. Towards a cognitive poetics of TV serial drama narrative: The case of Gomorrah - The Series', Journal of Screenwriting, 8:1, pp. 5-21.

Seger, Linda (2010), Making a Good Script Great, 3rd ed., Beverley Hills, CA: SilmanJames Press.

Skasgard, Alexander (2017), Big Little Lies, extras, New York, USA: HBO (Home Box Office).

‘Somebody’s Dead' (2017), David E. Kelley (wr.), About Big Little Lies, DVD extras, Season 1 Episode 1, New York, USA: (HBO [Home Box Office])

Smith, Murray (1995), Engaging Characters: Fiction, Emotion, and the Cinema, Oxford: Clarendon

Vallee, Jean-Marc (2017), Big Little Lies, DVD extras, New York, USA: HBO (Home Box Office).

Wheatley, Helen (2006), Gothic Television, Manchester and New York: Manchester University Press.

Margaret McVeigh has asserted their right under the Copyright, Designs and Patents Act, 1988, to be identified as the author of this work in the format that was submitted to Intellect Ltd. 